\title{
Understanding of economism and commercialization in the system of higher education: empirical analysis
}

\author{
Maryna Stryhul, Olena Khomeriki, and Marianna Khomeriki \\ National Aviation University, Kyiv, Ukraine
}

\begin{abstract}
The main point of the article is to analyze the essence of the phenomena of economism and commercialization in the system of higher education. Economism is seen as a part of globalization of education. It is noted that scientists argue that investments in education lead to the economic growth, reduce the income inequality and increase employment. It is worth noting that the processes of economization belong to the most important factors of the economic development of the country and cause social changes. Education is considered as a powerful factor of social development, social and economic progress and sustainable development of the social system. The aim of the article is to represent the phenomena of commercialization and economism in the system of higher education throughout the methods of sociological knowledge. It is mentioned that commercialization is one of the tendencies of education system change.
\end{abstract}

\section{Introduction}

Modern development of foreign education sociology is described in papers by M. Archer [1], R. Boudon [2], J. Coleman, N. Luhmann, J. Meyer, J. Passeron, B. Clark [3], S.Collini [4]. The mentioned authors consider the education system within the context of its social, typological and morphogenetic features, as an instrument of establishing distinctions, communication and habitualization. All the mentioned processes are in the system of education of both institutionalized and noninstitutionalized forms.

The attention of Ukrainian sociological community is constantly drawn to education as a social institution and social aspects of higher education. Special attention is to be paid to the achievements of the sociologists of the second half of the 20th century including A. Astakhova, O. Dikova-Favorska, V. Dobrenkov, V. Nechaiev, S. Oksamytna, A. Osypov, Y. Podolska, M. Rutkevych, L. Rubin, L. Sokurianska, M. Titma, V. Turchenko, F. Filippov, A. Shereha, S. Shchudlo, O. Yakuba and other scholars [8]. These authors studied issues regarding to the role of education in the development of the society, social mobility, life plans of youth and social characteristics of lecturers and teachers [17].

\section{Methods}

There have been conducted standardized questionnaire of students for the analysis of processes of economism and commercialization of the six higher education institutions of the 
state form of ownership - National Aviation University, National Pedagogical Dragomanov University, National Technical University of Ukraine "Igor Sikorsky Kyiv Politechnic Institute", Kyiv National Economic University named after Vadim Hetman, Kyiv National University of Trade and Economics, Kyiv National University of Technologies and Design, and 4 higher education institutions of private form of ownership - Kyiv International University (KIMU), the European University, Interregional Academy of Human Resource Management, the University of Modern Knowledge. There have been carried out (questionnaires on 31 and 20 questions) $(n=950$ : the stratified selection; controlled signs: "sex", "age", an error $\pm 2,1 \%$, reliable probability -95,45\%) and focus-group researches of students of NAU $(n=40)$.

The research was carried out in 2 steps.

The first stage included questionnaire of students. The second stage included a focusgroup student poll.

The first investigation phase consisted in studying of the features of commercialization at the National Aviation University and its influences on the quality of providing educational services (250 respondents).

The second stage consisted in studying of forms of manifestation of commercialization and economism in higher education of Ukraine (only 950 respondents).

\section{Theoretical basis}

In a certain relation the commercial environment, it was projected as an alternative education at the expense of budgetary funds. Not unreasonably the point of view according to which commercialization has allowed to survive higher education institutions in the conditions of chronic budgetary insufficient funding. However, on the term of nearly twenty years since the beginning of commercialization of Ukrainian higher education the intensity of discussion of its purposes, results and possible amendments don't decrease neither among experts, nor among the interested public. Supporters and opponents of commercialization note that education is that social branch which participates in the formation of prerequisites of the economic growth [10]. The state educational policy as a component of social policy is one of the instruments of influence of the state on formation of social structure and is directed to the solution of problems of societal level. It does relevant sociological examination of transformational processes in education and, in particular, results of commercialization. Thus, it is possible to claim that the educational system has the uncommon influence of globalization, forming a special system of the relations and interaction.

\section{Results}

The target audience of the research stood on different investigation phases.

Students of NAU (250 respondents from different institutes) took part.

For the purpose of formation of a complete picture have been chosen higher education institutions of an economic, humanitarian, pedagogical and technical profile.

By results of the conducted survey, it is noted that the reduction of the value of knowledge, increase in value of the diploma is characteristic for students of higher education institutions of the non-state form of ownership.

Higher education institutions of an economic profile are characterized considerably by bigger awareness in the use of entrepreneurial technologies, however, they don't understand the essence of the concept " Entrepreneurial University". Expert interviews have allowed to create ways of realization of the entrepreneurial ideas in the Ukrainian formation and transformation of the universities in the enterprise. 
Focus group research has revealed the tendency of the growth of the cost of training, a payment for additional educational services, development of second higher education, courses, trainings, etc. It doesn't influence on the improvement of material and technical resources of higher education institutions, teaching level, use of innovative technologies at all.

Economism and commercialization, according to our research, are corner processes in modern education. However, the level of understanding and knowledge on these questions even among students of higher educational institutions and teachers remains quite low [13].

In the Ukrainian higher education institutions commercialization is understood as an introduction of a payment for additional services, increase in the cost of training, the number of foreign students, the students of contract form of education and reduction of public financing of education.

It should be noted that it has a number of essential shortcomings as consider students a source and clients, and higher education institutions as institutions looking for profit in the form of capital. The Ukrainian higher education institutions have significantly different form of commercialization, which is focused on receiving the profit. Commercialization in the Ukrainian higher education institutions causes a catastrophic falling of the prestige of science and the value of education.

Higher education institutions of the non-state form of ownership, unlike the state, attract a large number of students, foreigners and, without having public financing, resort to such methods as increase in the cost of training, diversification of sources of financing and etc. There is a tough submission of the universities to the requirements of large business. Depreciation of diplomas is an observed prompt. Such phenomenon is a characteristic of higher education institutions in the non-state form of ownership [18].

Most of respondents don't understand, in fact the concept "economism", don't consider the need of higher education institutions to be engaged in the business activity and don't recognize the need of the existence of elements of business structures for higher education.

It is appropriate to carry out the analysis of manifestation of commercialization in the structure of each of the studied higher education institutions for the analysis of the state and non-state educational system.

The university has lost the prime appointment and became a huge supermarket, offering different types of knowledge. The rational action consists in the aspiration to take different types of knowledge. The rational action consists in the aspiration to buy the most qualitative goods, such as the diploma of the prestigious university which can be successfully converted into the official and economic status. The system of higher education of the student doesn't perceive as the successor of specific epistemological traditions of knowledge anymore. The intellectual model of students has been changing [9].

The above mentioned allows to speak about negative tendencies of commercialization and its manifestation in the structure of higher education, namely:

- firstly, the administration of higher education institutions and the faculty doesn't provide priority attention to improvement of quality of teaching;

- secondly, efforts of higher education institutions are directed on receiving profit in a clean form (from a tuition fee and investments of foreign citizens);

- thirdly, poor quality of teaching by the caused low orientation of higher education institution to innovative and creative activity, the outdated educational and methodical equipment, unsatisfactory material resources of higher education institutions, increase in load of teachers and decrease in level of their salary. Higher education institutions of an economic profile are more focused on innovative and grant activity (9\%), improvement of material and technical resources $(8 \%)$. The fact of improvement of quality of teaching $(7 \%)$ deserves attention.

Higher education institutions of the non-state form of ownership, unlike the state, are more focused on innovative and grant activity. For example, the University of Modern 
Knowledge $-10 \%$, Kyiv International University - 9\%, the European University $-11 \%$, Interregional Academy of Human Resource Management - 8\%.

In modern conditions the universities demand the increasing financing, therefore, there is a need for diversification of sources of financing.

Besides, it is necessary to concentrate attention on higher education institutions of the non-state form of ownership. Analyzing features of manifestation of commercialization, it has been noticed that:

- there is peculiar autonomy of higher education institutions of the non-state form of ownership which, in turn, provides increase in a tuition fee, introduction of a payment for additional educational services;

- the promptly diploma value increases, the value of knowledge decreases.

In general, the Kyiv National University of Trade and Economics, as well as the Kyiv National Economic University named after Vadim Hetman, are guided by the similar principles. Introduction of a payment for additional services (15\%), an increase in the cost of training (14\%) and reduction of value of knowledge, increase in value of the diploma (11\%) is noted.

On the basis of the conducted research a thesis about an education decline in quality, its scale, mass character, at the same time and high cost has been created conventional.

Consideration of private higher education institutions has allowed to compare all statistics and to define that private higher education in Ukraine which was more commercialized. A number of the university additional private services for the students are also focusing attention more not on dissemination of knowledge as a main objective of a higher educational institution, and on receiving means for results of the activity.

It should be noted that private higher education institutions focus the attention on innovation and grant activity and also are guided by the principles of diversifica- tion of sources of financing, arises one of commercialization manifestation forms.

The universities which have turned into agents of education market create the conditions of the cooperation with business. It, in turn, leads to open competition between higher education institutions, both on national, and at the global level. In similar conditions to replace accepted in the academic practice to joint methods of decision-making, based on reaching consensus, the practice of corporate business management comes, and the speed of decision-making is more important, than development of the coordinated position of mutual understanding. Therefore, the universities are more and more perceived as the scientific enterprises having own autonomy. However, this phenomenon is more inherent only in higher education institutions of private form of ownership as higher education institutions of the state form of ownership are on the state, providing, financing and control and the rights of own autonomy are often deprived [14].

Defining a commercialization problem in Ukraine, it is appropriate to concentrate attention on a question of public financing of the educational sphere. Most of respondents recognize the need of the existence of free education in Ukraine: 

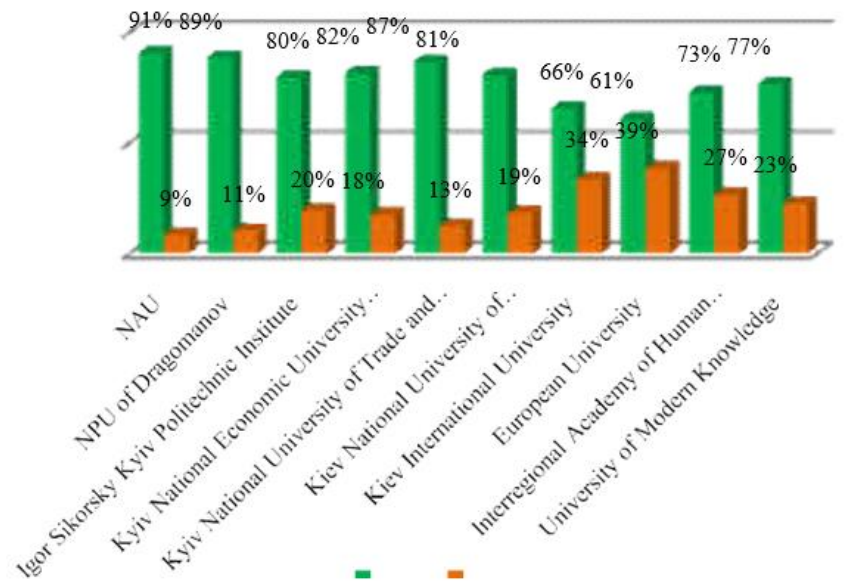

Fig. 1. The necessity of existence of free higher education in Ukraine, $\%$

Thus, the fact of existence of such indicator is denied. The population of Ukraine perceives higher education as a necessary component of the policy of the state and counts on the state support. Having the insignificant help from the state, higher educational institutions have to be able to provide the requirements of own higher education institution. Ensuring the state support doesn't guarantee of the skilful order public funds and, in turn, creates a number of obstacles.

Firstly, the system of higher education of Ukraine isn't calculated on diversification of sources of financing.

Secondly, outdated principles and traditions work in the educational system.

Thirdly, transformational and modernization processes in the educational sphere are necessary.

However, analyzing processes of commercialization of higher education, it is impossible to bypass a question of quality of education in general. It should be noted that $34 \%$ consider the quality of education, though $28 \%$ don't think so and $38 \%$ don't know the answer.

Collecting the data about existing the systems of ensuring quality of knowledge in higher education institutions, innovative models of quality management of education on the basis of educational standards, introductions of the principles of the Bologna declaration have to become the first steps in this direction. Together with its full and objective monitoring of quality of education has to be carried out. The quality and accreditation which is strongly connected among themselves put forward before not bad developed domestic system of licensing and accreditation the new tasks to use of the European quality standards and therefore our participation in the European network in ensuring the quality in higher education (ENQA) has already been obligatory in the nearest future.

The cost of higher education has to correspond its qualities (64\%). It is a quite natural phenomenon. However, payment cost on the highly prestigious specialties exceeds 30000 hryvnias (the average value calculated on the specialties of the National Aviation University, namely: "International Relations", "International Information", "International Business", "Journalism", "Tourism").

Considering necessary, the main objective of higher education has been defined: 


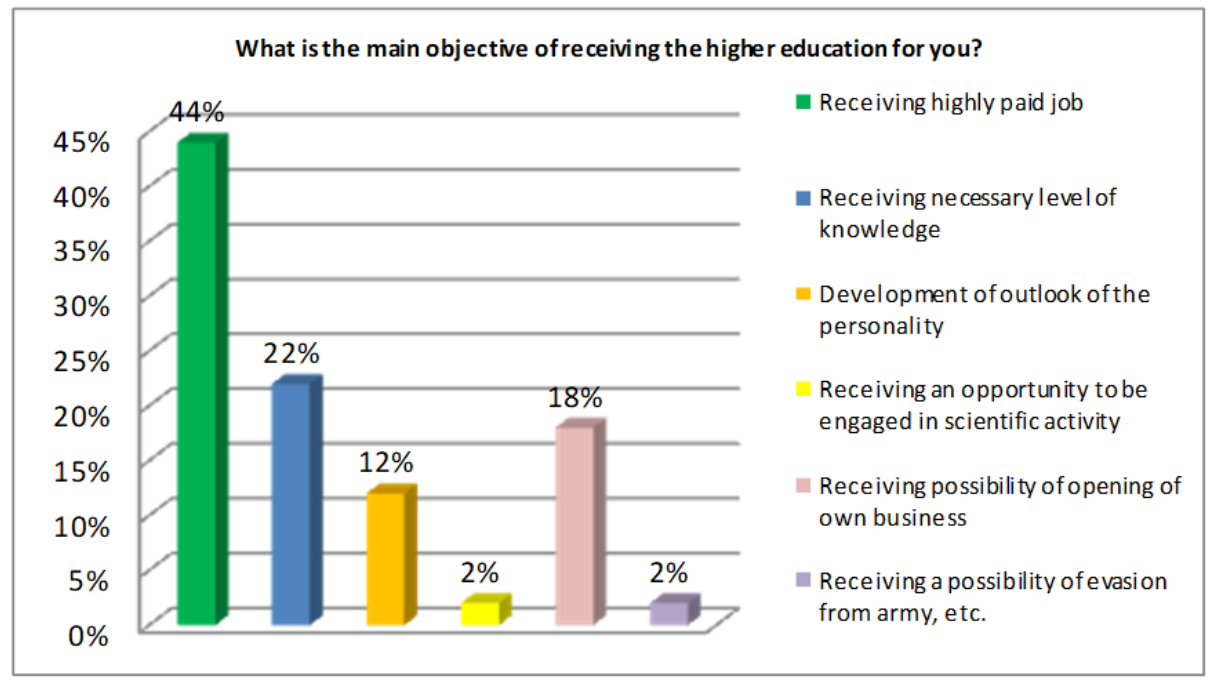

Fig. 2. Main objective of receiving higher education, $\%$

In modern conditions second higher education and additional education rise to some extent commercialization development factors. $85 \%$ of the interviewed respondents note the need of its receiving, and $66 \%$ note existence of need for second higher education in general.

Assistance in career development, desire of the organization of own business (18\%), selfdevelopment $(12 \%)$ arise motivation to receive additional and second higher education.

It is worth paying attention to such indicators, a criterion of the choice of educational institution. The majority prefers criterion of the data (94\%), criterion of popularity ( $83 \%)$, a criterion of the recommendation (82\%).

It should be noted that the Ukrainian society doesn't perceive a phenomenon of the Entrepreneurial University. It confirms a thesis that most of the respondents $(60 \%)$ don't recognize the existence of the principles of business in higher education institutions and, in particular, creation of entrepreneurial bases of the universities.

In general, on the basis of a research it is defined that Ukrainian society doesn't recognize economic bases of business at the universities, but their existence isn't denied in a scientific community. Analyzing characteristics of higher education institutions, it is recognized that competitiveness whereas $43 \%$ don't consider so, and a third part (28\%) don't know the answer. In general, it confirms the value of the diploma and recognizes that education is for getting the diploma, but not for knowledge, professional development and the place in the labor market.

However, a bright form of manifestation is higher than the designated tendency the following is: $85 \%$ of the interviewed respondents thought of receiving of second higher education whereas $15 \%$ of respondents reject such requirement. However, telling about essential a possibility of receiving second higher education, $66 \%$ of respondents are recognized by opinion that such requirement exists, but isn't relevant yet. $18 \%$ are noted by its relevance and $16 \%$ in general denies existence of require- ment of receiving a second higher education now.

$52 \%$ of respondents consider that they have no time for additional education, whereas $33 \%$ note that there is no financial opportunity. 
Did you think of receiving second higher education?

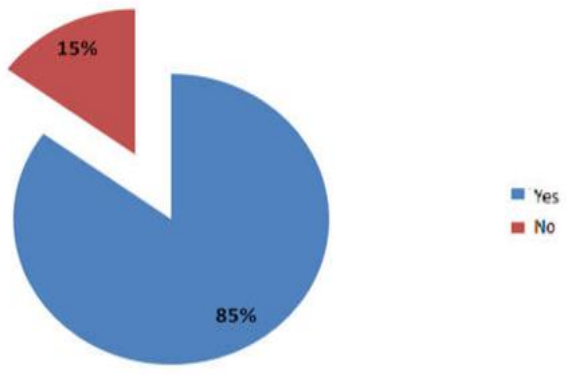

Fig. 3. Relation to receiving second higher education, $\%$

Increase in the number of students in contract form of education (14\%) in connection with reduction of public financing of higher education $(12 \%)$, introduction of payment for additional services (second higher education, courses, etc.) is defined. Deterioration in material and technical resources is noted (especially outdated equipment on technical specialties). Higher education institutions of an economic profile, unlike technical, are more focused on innovative and grant activity (9\%), improvement of material and technical resources $(8 \%)$. Deserves attention the fact of improvement of quality of teaching $(7 \%)$. Most of the respondents $(60 \%)$ don't recognize the existence of the principles of business in higher education institutions and, in particular, creation of entrepreneurial bases of the universities. On a main objective of education, it is established that $12 \%$ are engaged in obtaining the necessary level of knowledge but receiving highly paid work $-54 \%$. In general, it confirms a thesis that knowledge doesn't play the dominating role in modern society, and receiving profit has key value.

\section{Discussion}

As a present economic system, the state order doesn't reflect objectively public needs for experts with higher education. The feature of the educational system is that its normal functioning happens only when it isn't connected with the solution of temporary tasks, consider the prospects of economic development and growth of the need for certain experts. In the educational sphere all actions and the movements have to be weighed because they cause negative economic consequences. Development of economy and society assumes expansion of activity of the educational system. The special attention should be concentrated on higher education institutions of a technical profile as educational laboratories of technical colleges and engineering schools are created within many decades.

\section{Conclusions}

Everything in general promotes the emergence of Ukrainian forms of commercialization which differs from Western Europe. Its essential difference consists in tendentiousness, orientation on profit and consumerism, which is a peculiar type of consumer behavior. In the educational system the principles of consumerism are post- poned for introduction of payment for various additional services (trainings, advanced training courses etc.). The prospect of the creation of the entrepreneurial universities on the territory of Ukraine is rather farsighted, as commercialization mechanisms in Ukrainian education arise:

- adverse economic and social situation of the country in general;

- low, and sometimes unsatisfactory level of the state support of higher education; 
- insufficient financing of higher education institutions and the choice of irrational forms of government in the educational sphere;

- insufficient reforming of system of higher education;

- rapid development of private education and emergence of higher education institutions of non-state form of ownership;

- choice of ways of modernization of the educational sphere and insufficient support of the European educational tendencies;

- existence of a peculiar type of culture, mentality and consciousness of individuals that, actually, promotes rejection of innovations.

All this in general allows to define factors of manifestation of commercialization and economism in Ukrainian society and to claim that economism and commercialization are two separate social processes existing in the Ukrainian education system. However, the form of their dynamics and development remains quite peculiar.

At the same time, because of the existence of political and transformational factors, the system of higher education became more a source of cynicism and corruption and also negative moods in society. The innovative ideas, transformational strategy hasn't been carried out. However, higher education institutions together with the statesmen occupied in the management of the educational sphere bear considerable moral responsibility for similar miscalculations.

\section{References}

1. M. Archer, Sociology of Educational Development (London: Sage, 1979)

2. R. Boudon, La place du despordre: Critique destheories du changemen't social (Paris, 1985)

3. B. Clark, The Higher Education System: A Cross-National Perspective (Berkeley: University of California Press, 1983)

4. S. Collini, What are universities for? (London: Penguin Books (Amazon Kindle version, 2012)

5. O.A. Khomeriki, Dnipro: Grani, 8(124), 101 (2015)

6. S. Kniaz, N. Shpak, N. Myroshchenko, O. Kolomiyets, Econtechmod 3(1), 81 (2014)

7. J. Krauf, Ware Bildung, Schule und Universität unter dem Diktat der Ökonomie (Berlin, 2007)

8. L.V. Lebedeva, Business Inform 2, 65 (2017)

9. G. Ritzer, The McDonaldization of Society. New century ed. Thousand Oaks (Calif.: Pine Forge Press, 2000)

10. S. Borgohain, International Research Journal of Interdisciplinary \& Multidisciplinary Studies (IRJIMS)1(12), 71 (2016)

11. M. Sandel, What money can't buy: the moral limits of markets (London: Allen Lane, 2012)

12. S. Sani, Procedia - Social and Behavioral Sciences 122, 484 (2014)

13. M.V. Strigul, Habitus 5, 93 (2018)

14. M.V. Strigul, O.A. Khomeriki, Dnipro: Grani 21(4), 72 (2018)

15. P. Schulte, Higher Education in Europe 29(2), 187 (2004)

16. P. Scott, The Crisis of the University (London: Sydney Croom Helm, 1994)

17. Sociology of Education (New York: Routledge-Faimer, 2002) 
18. J. Spring, Globalization of Education (GB., 2014)

19. C. Taylor, The ethics of authenticity (Cambridge, Mass: Harvard University Press, 2003)

20. The University of the Future, http://www.esf.org/research-areas/socialsciences/news/ext-news-single-view/article/ the-university-of-the-future-468.html

21. N. V. Vasilenko, Fundamental research 4-1, 129 (2016)

22. E.T. Woldegiorgis, Higher Education Studies 3(2), 12 (2013)

23. S.M. Yagodzinsky, Bulletin of the National Aviation University. Series: Philosophy. Culturology: Collection of scientific works 2(24), 32 (2016) 